\title{
Effect of Organic Manures on Benefit Cost Ratio of Beet Root Cv. Crimson Globe
}

\author{
Chitti Jagadeesh*, M. Madhavi, M. Siva Prasad and V.V. Padmaja \\ Department of Vegetable Science, College of Horticulture, Dr.Y.S.R. Horticultural University, \\ Mojerla, Mahabubnagar, India \\ *Corresponding author
}

\section{A B S T R A C T}

\begin{tabular}{|l|}
\hline K e y w o r d s \\
Organic manures, \\
Green manure, \\
Vermicompost, \\
Benefit-cost ratio
\end{tabular}

Beetroot (Beta vulgaris L.), also called as garden beet or table beet, is one of the major root vegetable. It is grown in almost all states of India but in small scale only. It produces green tops and a swollen root used both as vegetable and salad. It is highly productive and usually free from pests and diseases (Ado, 1999). A field experiment was conducted during rabi, 2014 in alkali soils. The experiment was laid out in a randomized block design with three replicated 11 treatments viz., $\mathrm{T}_{1}$ : FYM (100\%), $\mathrm{T}_{2}$ : Vermicompost $(100 \%), \mathrm{T}_{3}$ : Neem cake $(100 \%), \mathrm{T}_{4}$ : Poultry manure $(100 \%), \mathrm{T}_{5}$ : Green manure $(100 \%)$, $\mathrm{T}_{6}: \mathrm{FYM}(50 \%)+$ Vermicompost $(50 \%), \mathrm{T}_{7}: \mathrm{FYM}(50 \%)+$ Neem cake $(50 \%), \mathrm{T}_{8}: \mathrm{FYM}$ $(50 \%)+$ Poultry manure $(50 \%), \mathrm{T}_{9}$ : FYM $(50 \%)+$ Green manure $(50 \%), \mathrm{T}_{10}: \mathrm{RDF}, \mathrm{T}_{11}$ : Control. The data were recorded on benefit-cost ratio of the crop. The highest benefit-cost ratio was recorded from $\mathrm{T}_{4}(4.1)$ with poultry manure $(100 \%)$, which was at par with $\mathrm{T}_{8}$ (4.1) with FYM $(50 \%)$ + poultry manure $(50 \%)$, These two treatments were recorded significantly high benefit-cost ratio than all other treatments. Control treatment showed (2.1) lowest benefit cost ratio.

\section{Introduction}

Beetroot (Beta vulgaris L.), also called as garden beet or table beet, is one of the major root vegetable belongs to the family Chenopodiaceae along with spinach, palak, swiss chard, parsley, celery and it has chromosome number of $2 n=18$. Beet originated in Western Europe and North Africa where they were grown to feed both humans and livestock. This crop is a biennial grown as a cool season annual. It is grown in northern and southern parts of India. It is grown in almost all states of India but in small scale only. It produces green tops and a swollen root used both as vegetable and salad. It is highly productive and usually free from pests and diseases (Ado, 1999). It is a rich source of protein, carbohydrate, calcium, phosphorous and vitamin $\mathrm{C}$, hence it is an ideal vegetable for health conscious people (Deuter and Grundy, 2004). Red color of roots is due to presence of betanine pigment. 
Organic farming is not mere non-chemical agriculture but it is a system integrating relationships between soil, plant, water, soil micro flora and fauna. Organic farming aims in creating a healthy soil, helps in proper energy flows in soil, crop, water, environment while the plant systems keeps biological life cycle alive and helps in sustaining considerable levels in yield (Lampkin, 1990).

For a sustainable crop production system, chemical nutrients removed by the crop must be replenished and physical conditions of the soil are to be maintained. Organic nutrient management provides excellent opportunities to overcome all the imbalances besides sustaining soil health and enhancing crop production. This optimizes the benefit from all possible sources of plant nutrients in an organic manner (Greenland, 1975). Organic manuring aims in creating a healthy soil, helps in proper energy flows in soil, crop, water, environment while the plant system keeps biological life cycle alive and helps in sustaining considerable levels in yield (Lampkin, 1990).

In view of increased awareness about organic manuring, increased availability of organic inputs and sustainability in the farm, investigation on these aspects have thus become imperative to study and assess their effect on benefit cost ratio of the crop beet root. Hence, this investigation is planned to identify benefit cost ratio of beet root by using different combination of organic manures in alkali soils.

\section{Materials and Methods}

A field experiment was conducted during rabi, 2014 in alkali soils, at college farm, College of Horticulture, Dr. Y.S.R. Horticultural University, Mojerla, Mahabubnagar(Dt). The experiment was laid out in a randomized block design with three replicated 11 treatments viz.,
$\mathrm{T}_{1}$ : FYM (100\%), $\mathrm{T}_{2}$ : Vermicompost (100\%), $\mathrm{T}_{3}$ : Neem cake $(100 \%), \mathrm{T}_{4}$ : Poultry manure $(100 \%), \mathrm{T}_{5}$ : Green manure $(100 \%), \mathrm{T}_{6}: \mathrm{FYM}$ $(50 \%)+$ Vermicompost $(50 \%), \mathrm{T}_{7}: \mathrm{FYM}$ $(50 \%)+$ Neem cake $(50 \%), \mathrm{T}_{8}:$ FYM $(50 \%)+$ Poultry manure $(50 \%)$, T9: FYM $(50 \%)+$ Green manure $(50 \%), \mathrm{T}_{10}$ : RDF, $\mathrm{T}_{11}$ : Control. The data were recorded on Table 1

\section{Economics of treatments}

The economics of different treatments were worked out in terms of net returns $\mathrm{ha}^{-1}$ and cost of the treatment.

The benefit : cost $(\mathrm{B}: \mathrm{C})$ ratio was also calculated treatment wise to ascertain economic viability of the treatment. Cost of production and net profit were calculated on the basis of prevailing prices of product and inputs.

\section{Results and Discussion}

The benefit cost ratio of Beet root crop by using different organic manures viz, FYM, vermicompost, poultry manure, neem cake and green manure is studied. The results of the present investigation on the above aspect are presented here under.

\section{Benefit-cost ratio}

The Benefit cost ratio shows the actual economic viability of any cultivation process. Benefit cost ratio of various treatments on beet root has been calculated and represented in table 1, The data reveals that application of organic manures has shown positive impact on economics of Beet root.

Among all the treatments it was beneficial to get maximum benefit cost ratio i.e. 4.1. It gave maximum gross income of Rs. 1,86,806 as well as maximum net income of Rs.1,50,216 from $\mathrm{T}_{4}$ with poultry manure $(100 \%)$. 
Table.1 Details of cost of cultivation in different treatments (rs. $\mathrm{ha}^{-1}$ )

\begin{tabular}{|c|c|c|c|c|c|c|c|c|c|c|c|c|}
\hline S. & Operations & T1 & T2 & T3 & T4 & T5 & T6 & T7 & T8 & T9 & & \\
\hline 1. & $\begin{array}{c}\text { Ploughing with Tractor } \\
\text { Harrowing }\end{array}$ & $\begin{array}{c}4,000 \\
800\end{array}$ & $\begin{array}{c}4,000 \\
800\end{array}$ & $\begin{array}{c}4,000 \\
800\end{array}$ & $\begin{array}{c}4,000 \\
800\end{array}$ & $\begin{array}{c}4,000 \\
800\end{array}$ & $\begin{array}{c}4,000 \\
800\end{array}$ & $\begin{array}{c}4,000 \\
800\end{array}$ & $\begin{array}{c}4,000 \\
800\end{array}$ & $\begin{array}{c}4,000 \\
800\end{array}$ & $\begin{array}{c}4,000 \\
800\end{array}$ & $\begin{array}{c}4,000 \\
800\end{array}$ \\
\hline 2. & Cost of Seeds & 4,000 & 4,000 & 4,000 & 4,000 & 4,000 & 4,000 & 4,000 & 4,000 & 4,000 & 4,000 & 4,000 \\
\hline b. & thinning & 2000 & 2000 & 2000 & 2000 & 2000 & 2000 & 2000 & 2000 & 2000 & 2000 & 2000 \\
\hline 3. & $\begin{array}{c}\text { Cost of Fertilizers/manures } \\
\text { Application charges }\end{array}$ & 8,844 & 28,000 & 32,200 & 17,790 & 29,000 & 18,422 & 20,522 & 13,317 & 18,922 & 2,744 & 000 \\
\hline 4. & Hand Weeding & 6,000 & 6,000 & 6,000 & 6,000 & 6,000 & 6,000 & 6,000 & 6,000 & 6,000 & 6,000 & 6,000 \\
\hline 5. & $\begin{array}{l}\text { Harvesting, Cutting } \\
\text { and Cleaning }\end{array}$ & 2,000 & 2,000 & 2,000 & 2,000 & 2,000 & 2,000 & 2,000 & 2,000 & 2,000 & 2,000 & $2, .000$ \\
\hline & TOTAL & 27,644 & 46,800 & 51,000 & 36,590 & 47,800 & 37,222 & 39,322 & 32,117 & 37,722 & 21,544 & 18,800 \\
\hline
\end{tabular}

The highest benefit-cost ratio was recorded from $\mathrm{T}_{4}$ (4.1) with poultry manure $(100 \%)$, which was at par with $\mathrm{T}_{8}$ (4.1) with FYM $(50 \%)+$ poultry manure $(50 \%)$, These two treatments were recorded significantly high benefit-cost ratio than all other treatments. Control treatment showed (2.1) lowest benefit cost ratio.

In conclusion, the highest gross returns (Rs. $1,87,384 \mathrm{ha}^{-1}$ ) were recorded with vermicompost $(100 \%)$. However, the net returns (Rs. 1,50,216 ha ${ }^{-1}$ ) and benefit cost ratio (4.1) were higher with poultry manure (100\%).Though RDF recorded maximum benefit cost ratio compared to these treatments, it is not advisable considering its possible effects on soil health and environment besides sustainability. Cultivation of beet root with organic manures, for obtaining maximum net returns and benefit cost ratio may be used as organic source of nutrient.

\section{References}

Ado, P.O., 1999. Beetroot Cultivation. Beetroot and Eggplant Newsletter, 18 $21-24$

Deuter, P. and Grundy, T. (2004). Beetroot Commercial Production and Processing. Agency for Food and Fibre Sciences. Holland Horticultural Limited Partnership. P. $1-4$.

Greenland, D.J. 1975. The magnitude and importance of the problem, pp. 3-7. In: D. J. Greenland and R. Lal (eds). Soil Conservation and Management in the Humid Tropics, John Wiley \& Sons, NY, USA.

Lampkin, N.1990. In: Organic farming, Ipswich, W.K., Farming Press Book, pp. 801-910.

\section{How to cite this article:}

Chitti Jagadeesh, M. Madhavi, M. Siva Prasad and Padmaja, V.V. 2018. Effect of Organic Manures on Benefit Cost Ratio of Beet Root Cv. Crimson Globe. Int.J.Curr.Microbiol.App.Sci. 7(11): 3612-3614. doi: https://doi.org/10.20546/ijcmas.2018.711.413 